\title{
CORRUPTION ONSET IN THE NINETEENTH CENTURY IN KAZAKHSTAN
}

Gaukhar Kaliyeva, Kazakh Legal-Humanitarian University, kalievag@list.ru

This study discloses the public officers' corruption at the end of $19^{\text {th }}$ century. I have post-evaluated tsarist Russia legislative acts. We have emphasized legal-social essence of corruption. We have tried to reveal and proof that giving presents and gifts in return for various assistance in a Kazakh society is a regular thing. We have manifested the reasons for corruption among the governmental officials. Based on the research we have concluded that corruption was distinctive for the governmental officials of the peripheral region because of its specific features, legal traditions and incomplete legislative system of Russia, which by the end of the $19^{\text {th }}$ century spread in Kazakhstan.

UDC Number: 35.081(574), DOI: 10.12955/cbup.2013.24

Key words: corruption, court system, public office, bribery, economic crimes

\section{Introduction}

Modern problem of corruption in the system of State Administration inevitably draws our attention to its social legal essence. Nowadays Kazakhstan pays close attention to fighting corruption (Ashitov, 2012; Durdyev, 2012; Zhumabayev, 2010). Legislation of Kazakhstan is developing and already consists of anti bribery laws, different state anti bribery programs and foresees criminal responsibilities for corruption crimes (Iskaliyeva, 2010; Kenzhegarina, 2012; Kozhamzharov, 2012). The history of corruption is as old as human civilization. This negative social phenomenon originates in ancient times (Izakhmetov, 2011; Turetskiy, 2011; Shokatayev, 2011). One of the corruption forming stages in Kazakhstan emerges at the time when Kazakhstan joined Russian Empire (Simonov, 2011). This factor stipulates its social legal essence.

Both foreign and native authors have done many scientific researches to study the corruption problem. Because of the specific nature of the crime, theses authors are usually law-enforcement agencies staff and institute researchers in the jurisprudence branch such as: Aitzhanov A., Ashitov B., Zhumabayev N., Kozhamzharov K., Simonov S., Turetskiy N., Shokatayev S. and Kaiser G. Main objectives of the research are peculiarities of economic crime like corruption and its social legal essence formation in Kazakhstan at the time of Russian Empire among the governmental officials. Other goals are to examine the motivation of corruption activities and bribery spreading among the governmental officials as well as bribery progress within the court system because of structural subdivisions changes. 


\section{Corruption as an economic crime}

First of all, corruption needs to be defined as a separate type of economic crime. Since there is no single concept of economic crime, it is impossible to classify such crimes either. Classification approaches are different. They group crimes by legal ground i.e. by the laws that were violated or by intrusion object. The other way, is to distinguish certain list of deeds that might be treated as economic. The best-reasoned classifications appear to be by certain grounds. Classification developed by German professor G. Kaiser might serve as a good example. He defines the group of economic crimes such as tax evasion, custom crimes, government grants fraud, blackmail, and bribery. Thus, according to G. Kaiser, bribery is one of the types of economic crimes. In its turn, according to specialists' opinion bribery is the most common and the most dangerous form of corruption (Aitzhanov, 2010). Pursuant to sources, exactly this form took place among governmental officials in Kazakhstan at the time of Russian Empire.

After government had introduced reforms in 1867-1868, general imperial court system and legislation spread across Kazakhstan territory. One of the most significant innovations in legal system was appearance of a new source of law - it was imperial legislation. All rules of law consisted of two groups. One group was rules of law for all the territories of Russian Empire. The other contained rules of law established specifically for Kazakhstan territory considering its regional peculiarities. Fundamental right suffered considerable change. Its main source became "yerezhe"1 which quickly adjusted to changing life conditions. Division between criminal and civil offences gained strength, nevertheless list of offences associated as criminal, constantly grew (Simonov, 2011).

Sweeping power, especially fiscal, made position of volost ${ }^{2}$ head a sweet spot for mammonish representatives of trade-usurious Kazakh upper class. Rival factions had a severe fight in elections, using both allowable and illegal methods. District head by all means was present during the elections and their opinion played pivotal role. Most of the time, district heads conspired with some of the candidates and received generous bribes. Corruption began to bloom both at district and volost' level.

Together with general imperial courts, “people's courts i.e. Biy’s ${ }^{3}$ courts” still existed. However these courts changed as well. Biy's post became elective. Electiveness and confirmation of biys by colonial authorities rendered opportunities for buying the post and for bribery in courts. Before $20^{\text {th }}$ century, Kazakhs could invoke any authoritative biy, whereas now they had to invoke only their volost' biys. The biys often made decisions in favor of their relatives and practiced bribery (Simonov, 2011).

Custom to give presents and all kinds of gifts has traditional feature, it is rooted to social-political and economic relationships that prevailed in Kazakh society during feudalism. Corruption appeared in legitimate institutional forms, its main factors at that time were: social differentiation by rich and poor, strict hierarchy between these two segments of the people according to their wealth, generic relation, and patriarchal structure. All this factors contributed bringing-up servility (Simonov, 2011).

The guidelines of fundamental Kazakh abridgement law "Zhete zhargy"4 are different. Covering all sides of Kazakh society they contain rules of criminal and civil law, religious guidelines as well as taxes and other. Devolution of power to the regions, absence of one single bureaucracy and feudal generic state administration together eliminate even a possibility of rules that would foresee the

\footnotetext{
${ }^{1}$ Yerezhe - court rules (translator's note)

${ }^{2}$ Volost' - administrative-territorial unit in Russia

${ }^{3}$ Biy - administrative title

${ }^{4}$ Zhete zhrgy - abridgement of Kazakh khanate law
} 
responsibility for bribery and abuse of the position otherwise stated responsibility for corruption (Simonov, 2011).

The next step, which influenced the change in social-legal essence of the corruption, began during the period of Russian Colonial Policy adoption and Russian Empire's boarder expansion. At the period when Kazakhstan was joining Russia judicial system had two active systems in parallel.

1. Local national courts - biy's courts and qadi's courts. They examined only insignificant criminal and civil cases between Kazakhs. Adat and sharia were their guidelines.

2. General imperial court establishments that examined only major cases of Kazakhs, and all cases arisen between representatives of different ethnicities (Simonov, 2011).

In $18^{\text {th }}-19^{\text {th }}$ centuries they see corruption in Kazakhstan from the Colonial politics' point of view. During the period of Romanov's dynasty reign, corruption was an item of income for petty officials and dignitaries (Simonov, 2011).

Toughening and punitive measures did not reduce this type of crime. Therefore, in tsarist Russia they started to look for a new approach fighting corruption. It had to ensure expansion reasons identification and ways to eliminate them. Under Nikolai the $2^{\text {nd }}$ rule, in 1845 they adopted new penal code which considerably complements the legislation about responsibility for bribery and other forms of corruption. In chapter 6 of the $5^{\text {th }}$ section they foresee criminal responsibility for position abuse, including bribery. This chapter is called "About graft and extortion". It consisted of 13 articles (Simonov, 2011).

In November of 1862 imperator Alexander the $2^{\text {nd }}$, decrees "About finding reasons and means of plague extirpation".

1. What are the reasons for the graft in the Empire? They not only exist, but also spread among those who must fight them.

2. Are the existing graft laws complete? Don't they patronize the exactors... since exactor and giver have the same punishment?

3. What measures shall be taken to demolish this plague so it wouldn't harm justice, State structure or quick case closure?

Senate created a special committee to investigate this issue. It indicated three main reasons of its spread: incomplete laws, low and insufficient material and financial situation of governmental officials, inadequacy of crimes and punishments. "Russian legislation has no differentiation between crimes committed because of greed and profit and forced by poverty. Those who steal from the Government, who extort last money from the one in need, and those poor clerks who got few rubles from the suppliant to please; they all shall be subjected to the same punishment." (mentioned decree of Alexander the $2^{\text {nd }}$ ).

In the beginning of $20^{\text {th }}$ century, in 1903 government developed Russian "Criminal Code", where they transferred all the rules about official crimes from the previous code of 1885. It was blanket, causing difficulties and inconvenience identifying violated rules of codes. Nevertheless it was much more modern than the previous code. It also enabled new, simplified criminal legislation system, where they have managed to define authorities.

However, in reality modern legislators faced difficulties connected with malfeasance qualification. Main difficulty was to separate crimes committed by governmental officials at State service from the similar that commercial and other organizations authorities committed. That happened because of the absence of authority conception definition in the code (Simonov, 2011). 
Governmental commission of a new Criminal Code project in 1903 had the same problem with classification. Under the influence of penal justice practical needs, commission had to comply and introduce the corresponding "officer" definition into the regulations text, which, with some modifications has entered the final edition of legislation. Art. 636 of Chapter 37 "About criminal conduct at the state and public service" of the Criminal Code defined as: "officer is every person in charge or executing a temporary State or public service, assignment as an officer, or a police officer or a guardian, or a minister, or a person rural or middle-class management" (Simonov, 2011).

\section{Conclusion}

We can conclude, that in the period of new legal system formation, specific features of historically embodied traditions caused corruption among the governmental officials in Kazakhstan. In central regions of Kazakhstan officers accepted bribes because of the lack of financial stability, whereas in border regions of Russia they provoked and encouraged bribery to oppose the local government to the colonial one. Corruption became common in considered time. Paradoxically, but this was one of the few methods to strengthen the colonial regime in Kazakhstan, which by the end of the nineteenth century was no longer a subject of international law.

\section{References}

Aitzhanov, D. R. (2010). The most common type of corruption - Bribery. Femida, 11, 2-5.

Ashitov, B. (2012). Corruption in the system of the state regulation. Law and time, 5, 21-25.

Durdyev, R. (2012). Corruption as a negative phenomenon. Femida, 11, 20-24.

Iskaliyeva, A. (2010). Corruption - of all states of world society. Femida, 12, 34-35.

Izakhmetov, B. (2011). Fight against corruption - significant step in formation of constitutional state. Femida, 4, 35-37.

Kaiser, G. (1987). Economic crime and its control with special reference to the situation in the Federal Republic of Germany. Warsaw, Poland: Enro Kriminology.

Kenzhegarina, Z. (2012). Concept of corruption, its signs and historical aspects. Femida, 4, 18-21.

Kozhamzharov, K. (2010). Fight against corruption shall be the problem of the whole nation. Law and time, 9, 5-10.

Shokatayev, S. (2011). Problems of development of criminal science in the sphere of fight against corruption crimes. Law and time, 11, 48-51.

Simonov, S. (2011). Retrospective analysis of examination of terms "corruption" and "corruptional activity" in Kazakhstan. Law and time, 4, 59-64.

Turetskiy, N. (2011). Analysis of anticorruption policy in the modern stage. Law and time, 9, 11-17.

Zhumabayev, N. (2010). Today fight against corruption is the most important task. Femida, 8, 2-4. 